\title{
MAKING FAST STRATEGIC DECISIONS IN HIGH-VELOCITY ENVIRONMENTS
}

\author{
KATHLEEN M. EISENHARDT \\ Stanford University
}

\begin{abstract}
How do executive teams make rapid decisions in the high-velocity microcomputer industry? This inductive study of eight microcomputer firms led to propositions exploring that question. Fast decision makers use more, not less, information than do slow decision makers. The former also develop more, not fewer, alternatives, and use a two-tiered advice process. Conflict resolution and integration among strategic decisions and tactical plans are also critical to the pace of decision making. Finally, fast decisions based on this pattern of behaviors lead to superior performance.
\end{abstract}

In October 1984, Gavilan Computer filed for bankruptcy protection under Chapter 11. Despite a \$31 million stake from venture capitalists, Gavilan experienced delays and indecision that ultimately cost the firm its early technical and market advantages. The firm's leading-edge technology became a "me too" one and competitors flooded its empty market niche. As the firm died, one executive mourned: "We missed the window" (Hof, 1984).

This story is not unusual in fast-paced settings like the microcomputer industry. The tumult of technical change places a premium on rapid decision making. Yet, although decision speed seems to affect firm performance in such environments (Bourgeois \& Eisenhardt, 1988) and is a key characteristic differentiating strategic decisions (Hickson, Butler, Gray, Mallory, \& Wilson, 1986), there has been little research on fast strategic decision making.

This article explores the speed of strategic decision making. In an earlier study (Bourgeois \& Eisenhardt, 1988), my colleague and I linked fast strategic decision making to effective firm performance. In a second study on politics (Eisenhardt \& Bourgeois, 1988), we noted that politics seemed to

I would like to give special thanks and acknowledgment to my friend and colleague, Jay Bourgeois, especially for his instrument design and data collection efforts. Also, I would like to thank my graduate assistants, Theresa Lant, Mike Boehm, Anita Callahan, Dave Ellison, and Paul McCright. Finally, I have benefited from the insightful comments of the following: Paul Adler, Phil Bromiley, Jim Dean, Greg Dess, Connie Gersick, Jim Jucker, Bob Keeley, Jim March, Kaye Schoonhoven, Bob Sutton; my excellent reviewers; and participants in the 1988 Asilomar, University of California, Berkeley, Organizations, and Stanford Department of Industrial Engineering and Engineering Management seminars.

This research was supported by a grant from the Decision, Risk, and Management Sciences Program, National Science Foundation, grant number SES-8813329. 
slow decision making. However, neither study addressed how executives decide quickly. The present study extends the previous work by exploring how executive teams actually make fast decisions.

This article is organized around two research questions: (1) How are fast strategic decisions made? and (2) How does decision speed link to performance? The setting is the high-velocity microcomputer industry. In a highvelocity environment, changes in demand, competition, and technology are so rapid and discontinuous that information is often inaccurate, unavailable, or obsolete (Bourgeois \& Eisenhardt, 1988). During this research (1984-85), the microcomputer industry underwent substantial technological changes, such as the introduction of the UNIX operating system, 64K RAM memory, and RISC computer architecture, as well as substantial competitive change, such as the entry of IBM, the decline of Texas Instruments, and double-digit demand growth (Bell, 1984).

The results reported here are a set of propositions challenging traditional views of strategic decision making. The evidence suggests that fast decision makers use more, not less, information, than do slow decision makers. They also develop more, not fewer, alternatives. In contrast to current literature, this study found that centralized decision making is not necessarily fast, but a layered advice process, emphasizing input from experienced counselors, is fast. The findings also indicate that conflict resolution is critical to decision speed, but conflict per se is not. Finally, integration among strategic decisions and between decisions and tactical plans speeds, not slows, decision making. Such integration helps decision makers cope with the anxiety of high-stakes decision making. Overall, fast decision making allows decision makers to keep pace with change and is linked to strong performance. A pattern of emotional, political, and cognitive processes that are related to rapid closure of major decisions emerged from this research. The empirical grounding of those ideas is the subject of this article.

\section{BACKGROUND}

There are several perspectives on how rapid strategic decisions are achieved. One research stream emphasizes the idea that a high level of comprehensiveness ${ }^{1}$ slows the strategic decision process. According to this perspective, consideration of few alternatives, obtaining input from few sources, and limited analysis lead to quick decisions (Mintzberg, 1973; Nutt, 1976). For example, Fredrickson and Mitchell (1984) argued that a process that is less comprehensive speeds decisions. Similarly, Schweiger, Sandberg, and Ragan (1986) noted that extensive analysis in dialectical inquiry is

1 "Comprehensiveness is a measure of rationality and refers to the extent to which organizations attempt to be exhaustive or inclusive in the making or integrating of decisions" (Fredrickson \& Mitchell, 1984: 399). 
likely to slow the pace of decision making. Janis (1982) indicated that, although a rational process may be superior, it also lengthens decision making.

A second view has emphasized that limited participation and centralized power speed decision making. For example, Vroom and Yetton (1973) advocated autocratic decision making when speed is essential. Powerful leaders can make rapid, unilateral choices. Similarly, March and Olsen (1976) argued that involvement by many decision makers lengthens the decision process. Finally, Staw, Sandelands, and Dutton (1981) indicated that power centralization is the most natural response to highly uncertain situations like high-velocity environments.

A third view is that limited conflict speeds decisions. The argument here is that conflict triggers interruptions in the decision process, which then slow the pace. For example, Mintzberg, Raisinghani, and Theoret (1976) found that disagreements created decision interruptions, which in turn delayed the decision process in a study of 25 major decisions. Similarly, another study (Hickson et al., 1986) found that opposition, especially by powerful factions, slowed the pace of decision in a study of British organizations.

Although these views vary in detail, none deals with two key realities. First, how do decision makers overcome anxiety and gain the confidence to decide? As George (1980) noted, many individuals find it difficult to make big decisions in the face of high uncertainty. Yet such uncertainty is typical of strategic decisions, especially in high-velocity environments. So how do decision makers overcome their natural proclivity to procrastinate, especially when information is limited? Second, how do decision makers maintain decision quality while moving quickly? The existing views rest on the assumption that fast decisions are achieved through a less thorough strategic decision-making process involving limited information, analysis, participation, and conflict. However, as Bourgeois and Eisenhardt (1988) noted, there is pressure for both a rapid and high-quality decision process, especially in high-velocity environments. Is the snap decision process described by existing views realistic?

These questions suggest that extant views may inaccurately describe how executives make rapid decisions. This observation, coupled with the limited research base on fast strategic decision making, led to the inductive research described in this paper.

\section{METHODS}

The study used a multiple case design that allowed a replication logic, that is, a series of cases is treated as a series of experiments, each case serving to confirm or disconfirm the inferences drawn from the others (Yin, 1984). Table 1 describes the eight microcomputer firms studied.

The study also employed an embedded design, that is, multiple levels of analysis, focusing on each firm at three levels: (1) top management team, (2) 
TABLE 1

Descriptions of Microcomputer Firms

\begin{tabular}{lcc}
\hline Firm & $\begin{array}{c}\text { Number of } \\
\text { Employees }\end{array}$ & $\begin{array}{c}\text { Number of } \\
\text { Informants }\end{array}$ \\
\hline Zap & 500 & 7 \\
Forefront & 90 & 7 \\
Promise & 185 & 6 \\
Triumph & 150 & 7 \\
Omicron & 192 & 9 \\
Neutron & 200 & 7 \\
Alpha & 50 & 5 \\
Presidential & 462 & 5 \\
\hline
\end{tabular}

strategic decision, and (3) firm performance. Although an embedded design is complex, it permits induction of rich and reliable models (Yin, 1984).

\section{Data Sources}

Members of the research group conducted interviews with every member of the top management team of each firm, including CEOs and their immediate subordinates. The teams typically included the CEO and the heads of such major functions as sales, finance, and engineering.

There were four data sources: (1) initial CEO interviews, (2) semistructured interviews with each member of a firm's top management team, (3) questionnaires completed by each member of the team, and (4) secondary sources.

CEO interviews. An entry interview, using a semistructured format, was conducted with the CEO of each firm. The interview began by asking the CEO to describe the firm's competitive strategy. The CEO was then asked to describe the distinctive competencies of the firm, major competitors, and their performance. Each CEO then identified several recent or ongoing major decisions. The decision or decisions to study in depth in subsequent interviews with each member of the top management team were then chosen. The choices were based on criteria similar to those other researchers have used for defining strategic decisions (Hickson et al., 1986; Mintzberg et al., 1976). ${ }^{2}$ To be chosen, a decision had to (1) involve strategic positioning, (2) have high stakes, (3) involve as many of the functions of the firm as possible, and

\footnotetext{
${ }^{2}$ Ideally, many strategic decisions would have been studied in each firm. However, doing so was almost impossible because strategic decisions are infrequent events. The approach here was to triangulate insights from one or two decisions with evidence on the overall approach to strategic decision making within the firm. The validity of this approach is enhanced by previous research indicating that firms make decisions in a consistent pattern (Fredrickson \& Iaquinto, 1987; Miles \& Snow, 1978; Nystrom \& Starbuck, 1984), even when the top management team experiences turnover in individual positions (Weick, 1979).
} 
(4) be considered representative of the process by which major decisions are made at the firm. ${ }^{3}$

Top manager interviews. After the initial CEO interview, semistructured interviews with every executive in the top management team, including the CEO, were conducted. The interview consisted of 16 open-ended questions. Following the methods of inductive research, these questions were supplemented with ones that seemed fruitful to pursue during the interview. The interviews were typically from 90 minutes to two hours long but occasionally took as long as four hours.

The interview began with a request for a description of the firm's competitive strategy. Each executive then described the functional strategy of his or her area, other members of the top management team, the frequency and nature of interaction with each other member of the team, and routine decision-making meetings. Thus, a general view of the strategic decision process within the firm emerged.

In the second portion of the interview, the story of each strategic decision identified in the CEO entry interview was traced. This yielded a view of specific decision processes within the firm. The perspective of every member of the top management team was traced using standard interview questions. The questions concentrated on facts and events, rather than on respondents' interpretations, through the use of courtroom procedure (e.g., When did this first become an issue? What did you do? When?).

Two investigators conducted each interview with one responsible for the interview and the other for taking notes. Immediately after the interview, the investigators cross-checked facts and impressions. Several rules were followed. The "24-hour rule" required that detailed interview notes and impressions be completed within one day of the interview. A second rule was to include all data, regardless of their apparent importance at the time of the interview. A third rule was to end the interview notes with ongoing impressions of each company.

The combination of multiple informants, courtroom-style questioning, and tandem interviewing addresses some previous criticisms of research relying on executives' recollections (Schwenk, 1985). Moreover, previous research (Huber, 1985; Mintzberg et al., 1976) has indicated high temporal stability in executives' recollection of important decisions, especially for major recent decisions.

Questionnaires. Quantitative data were gathered from questionnaires. The questions focused on variables, such as conflict and power, suggested by prior research on decision making (e.g., Mintzberg et al., 1976; Pfeffer, 1981). The Appendix describes the questions and their administration.

Secondary source and other data. Industry reports and internal docu-

${ }^{3}$ One decision was studied in depth at every firm except Omicron and Triumph. In those two firms, two decisions fit the selection criteria; both were subsequently studied to provide more solid empirical grounding for the propositions. 
ments were examined as available. Informal observations were made, and data were collected on office locations, team demographics, and financial performance before and after the study. Finally, observations of a day-long strategy-making session in one firm and a weekly executive staff meeting in another were conducted.

\section{Data Analysis}

The data were analyzed as follows. For the quantitative data, team level scores of conflict and power were calculated and analyzed for patterns. The qualitative responses were combined using profiles of the decision climates and of each executive from the descriptions each member of the top management teams had given. Traits mentioned by more than one executive were included in the profiles. For example, three of his four colleagues described the president of Alpha as "impatient."4 This trait was included in his profile, but other traits mentioned by only one person were dropped.

Decision stories were developed by combining the accounts of each executive into a time line that included all events. There was typically high agreement among respondents around the critical issues of when a decision began, when the decision was made, and how it was made. Again using Alpha as an example, the executives all agreed that the impetus for the decision studied was a specific board meeting, that the CEO made the decision alone, and that he did so just before the annual planning conference. Although they were few, conflicting reports were preserved in the stories. These usually concerned one person's assumptions about another's motives or opinions, not observable actions and events.

Once preliminary analyses had been developed from the respective data sets, I combined the analyses and induced propositions using methods for building theory from case studies (Eisenhardt, 1989; Glaser \& Strauss, 1967). The search for propositions was assisted by selecting pairs of firms and listing similarities and differences between each pair and by categorizing firms according to variables of interest, such as the presence or absence of a counselor to the CEO. From these lists and comparisons, I induced tentative propositions. After the development of these tentative propositions, each case was revisited to see if the data confirmed the proposed relationship, and if they did, to use the cases to improve understanding of the underlying dynamics. After many iterations between data and propositions, I used existing literature to sharpen the insights yielded by the inductive process. What emerged were propositions linking information, alternatives, advice, conflict resolution, and integration with decision speed and performance. As in deductive research, the propositions fit the evidence but did not perfectly explain the cases (Sutton \& Callahan, 1987).

\footnotetext{
${ }^{4}$ The names used to identify the firms studied are pseudonyms.
} 


\section{HOW ARE FAST STRATEGIC DECISIONS MADE?}

\section{Speed, Planning, and Real-Time Information}

Prior research has suggested that comprehensiveness slows the strategic decision-making process (Fredrickson \& Mitchell, 1984). Consideration of few alternatives, obtaining inputs from few sources of expertise, and limited analysis shorten the strategic decision process Janis, 1982; Mintzberg et al., 1976; Nutt, 1976). This perspective implies that the greater the use of information, the slower the strategic decision process.

The data from this research indicate a different view. Executive teams making fast decisions used extensive information-often more information than the slower decision makers used. However, that information was not forecasted information. Rather, it was real-time information, especially on a firm's competitive environment and operations. Real-time information is defined as information about a firm's operations or environment for which there is little or no time lag between occurrence and reporting. In formal terms,

Proposition 1: The greater the use of real-time information, the greater the speed of the strategic decision process.

Table 2 summarizes this study's evidence on the speed of decision making. I assessed the overall speed of decision making from interview and story data. These qualitative assessments were corroborated with measurement of the duration of each strategic decision studied. Following prior research (Hickson et al., 1986; Mintzberg et al., 1976), I measured duration using the beginning and end times for each decision, with starting time indicated by the first reference to a deliberate action such as scheduling a meeting or seeking information and ending time indicated by the time at which a commitment to act was made.

As Table 2 indicates, there was high variation in the speed of decision making. The first four firms listed-Zap, Forefront, Promise, and Triumph-made the decisions that were studied in less than 4 months, and substantial evidence from the interviews and stories corroborated that such a fast pace was typical. For example, most Promise executives mentioned without prompting that they made decisions "quickly," and their making a decision on strategic direction in 4 months is consistent with the data. Throughout this article, those four firms are referred to as fast. The second four firms-Omicron, Neutron, Alpha, and Presidential-spent at least 6 months, and typically more than 12 months, making the decisions that were studied, and the qualitative evidence (see Table 2) corroborated that this slower pace was typical. Thus, I refer to those firms as slow.

Table 3 summarizes the evidence for the use of real-time information, which was assessed by (1) executive responses to interview questions regarding the regular review of performance measures and targets, (2) a count of the number of meetings regularly scheduled to review current operations, 
TABLE 2

Speed of Strategic Decision Making

\begin{tabular}{|c|c|c|c|}
\hline Firm & Examples $^{a}$ & $\begin{array}{l}\text { Decisions and } \\
\text { Key Questions } \\
\end{array}$ & $\begin{array}{l}\text { Decision } \\
\text { Durations } \\
\text { in Months }\end{array}$ \\
\hline Zap & $\begin{array}{l}\text { "We try to be the first." (VP, } \\
\text { engineering) } \\
\text { "If we get bogged down, he } \\
\text { [CEO] kicks ass." (VP, } \\
\text { marketing) } \\
\text { "The worst decision is no } \\
\text { decision at all." (CEO) }\end{array}$ & $\begin{array}{l}\text { Alliance: Should we form a } \\
\text { strategic alliance or go } \\
\text { public? }\end{array}$ & 3 \\
\hline Forefront & $\begin{array}{l}\text { "We're aggressive. We make } \\
\text { things happen." (director of } \\
\text { marketing) } \\
\text { "Big opportunities go by if } \\
\text { you don't act quickly." } \\
\text { (VP, sales) }\end{array}$ & $\begin{array}{l}\text { New product: Should we } \\
\text { develop a new product? }\end{array}$ & 2 \\
\hline Promise & $\begin{array}{l}\text { "I like quick decisions." } \\
\text { (CEO) } \\
\text { "We make decisions fast." } \\
\text { (VP, systems development) }\end{array}$ & $\begin{array}{l}\text { Strategy: Do we need a new } \\
\text { strategic direction? }\end{array}$ & 4 \\
\hline \multirow[t]{2}{*}{ Triumph } & $\begin{array}{l}\text { "Decision making at Triumph } \\
\text { is much faster." (VP, }\end{array}$ & $\begin{array}{l}\text { Strategy: Do we need a new } \\
\text { strategic direction? }\end{array}$ & 1.5 \\
\hline & $\begin{array}{l}\text { finance) } \\
\text { "He [CEO] listens, makes up } \\
\text { his mind, and does it. He's } \\
\text { made the decision process } \\
\text { shorter." (VP, sales) } \\
\text { "Do something, don't just sit } \\
\text { around worrying." (CEO) }\end{array}$ & $\begin{array}{l}\text { New product: What should } \\
\text { our next product be? }\end{array}$ & 1.5 \\
\hline \multirow[t]{2}{*}{ Omicron } & $\begin{array}{l}\text { "Slow moving." (VP, } \\
\text { manufacturing) }\end{array}$ & $\begin{array}{l}\text { Strategy: Do we need a new } \\
\text { strategic direction? }\end{array}$ & 12 \\
\hline & $\begin{array}{l}\text { "There was a frustrating } \\
\text { amount of decorum. } \\
\text { Consensus was very } \\
\text { important." (VP, sales) } \\
\text { "We did what we intended, } \\
\text { but took longer than we } \\
\text { should have." (CEO) }\end{array}$ & $\begin{array}{l}\text { Strategy: What should our } \\
\text { new strategy be? }\end{array}$ & 6 \\
\hline Neutron & "We were late." (VP, finance) & $\begin{array}{l}\text { Alliance: Should we form a } \\
\text { strategic alliance? }\end{array}$ & 12 \\
\hline Alpha & $\begin{array}{l}\text { "We never did anything } \\
\text { concentrated ... no } \\
\text { particular dedicated time } \\
\text {... things kind of } \\
\text { evolved." (VP, sales) } \\
\text { "We were kind of casting } \\
\text { around." (VP, finance) }\end{array}$ & $\begin{array}{l}\text { New product: Should we } \\
\text { develop an IBM-compatible } \\
\text { product? }\end{array}$ & 12 \\
\hline
\end{tabular}


TABLE 2 (continued)

\begin{tabular}{|c|c|c|c|}
\hline Firm & Examples $^{\text {a }}$ & $\begin{array}{l}\text { Decisions and } \\
\text { Key Questions }\end{array}$ & $\begin{array}{c}\text { Decision } \\
\text { Durations } \\
\text { in Months }\end{array}$ \\
\hline Presidential & $\begin{array}{l}\text { "Presidential was unfocused. } \\
\text { We weren't concentrated." } \\
\text { (EVP) } \\
\text { "Lots of arguments-no } \\
\text { decisions." (VP, } \\
\text { manufacturing) } \\
\text { "There was no structure .... } \\
\text { nothing got accomplished." } \\
\text { (VP, R\&D) } \\
\text { "Nothing happened ... It } \\
\text { was so hard to get ideas } \\
\text { through." (EVP) }\end{array}$ & $\begin{array}{l}\text { New product: Should we } \\
\text { develop a new product? }\end{array}$ & 18 \\
\hline
\end{tabular}

${ }^{a} \mathrm{VP}=$ vice president EVP $=$ executive vice president.

(3) the presence of a vice president (VP) of finance-typically the key provider of real-time information in firms like those studied-and (4) the orientation of a firm's CEO toward information. Executives' preferences for various communication media and the use of real-time information in the making of the strategic decisions studied in each firm were also noted.

The data shown in Tables 2 and 3 indicate that fast strategic decision making is associated with extensive use of real-time information. Executives making fast decisions routinely paid close attention to quantitative indicators such as daily and weekly tracking of bookings, scrap, inventory, cash flow, engineering milestones, and competitors' moves. They preferred these operational indicators to more refined accounting data such as profit. These executives averaged 2.5 regularly scheduled operations meetings per week and indicated a preference for real-time communication via face-to-face conversation or electronic mail rather than through time-delayed media like memos.

The Zap case illustrates the linkage between the use of real-time information and decision speed. Zap executives claimed to "measure everything." Without prompting, the CEO described exact targets for gross margin and expenses for R\&D, sales, and administration. Executives reviewed bookings daily. Engineering schedules were reviewed weekly. The VP of finance ran a computer model of firm operations weekly. The VP of marketing monitored the environment continuously. As she told us, "I keep an eye on the market [and] funnel the information back." The R\&D VP told us that he monitored the technology "grapevine" through his extensive network of friends. Monthly, the executive team reviewed a wide range of quantitative indicators, including revenue per employee, margins, backlog, scrap, cash, and inventory. This is a much more comprehensive set of indicators than the teams making the slower decisions used. Zap's CEO told us: 


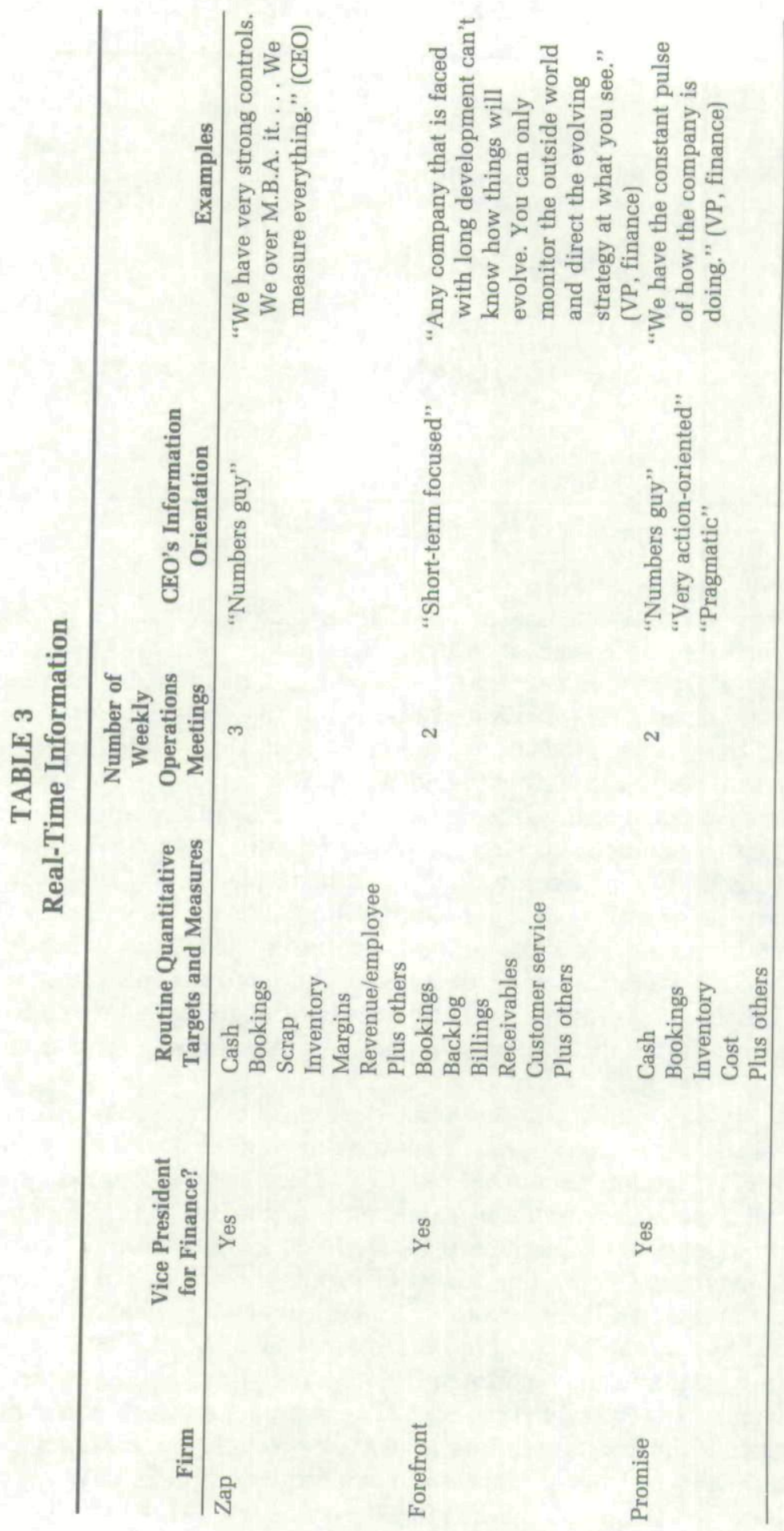




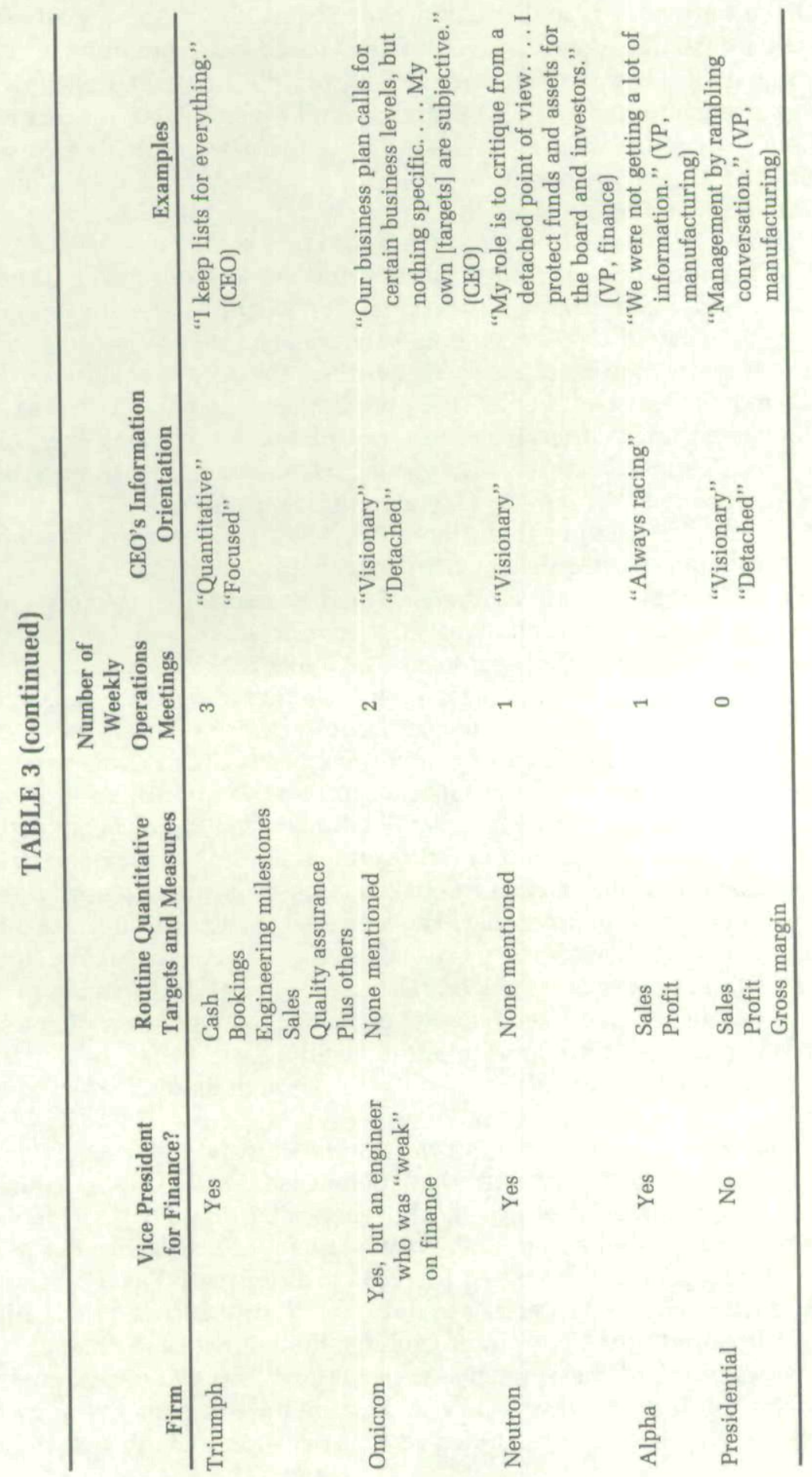


"We have very strong controls. We over M.B.A. it." Zap executives also reported interacting continually through face-to-face communication and electronic mail. They avoided memos. For example, one executive described her communication with the CEO and several other VPs as "constant." Finally, the decision to forge a strategic alliance that was studied was triggered by the team's cash projection model, which predicted an upcoming cash shortfall. Zap executives made this decision in three months. A Zap executive claimed: "The worst decision is no decision at all."

The Triumph case also indicates the link between use of real-time information and rapid strategic decisions. For example, the first employee hired by the current CEO was a data-base manager whose job was to track new product development projects, the lifeblood of microcomputer firms. Firm members described the CEO as "quantitative," and he claimed to "have lists for everything." Interviewees described the weekly staff meetings at Triumph as "a must." One executive said, "No one travels on Mondays." My own visit revealed that the Monday meetings were intense. The day began with a four-hour meeting that "[covered] what's happening this weekwhat's happening with sales, engineering schedules, and releases." In the afternoon, Triumph executives attended quality assurance and new-product progress meetings. The executives also conducted regular "round table" forums at which lower-level employees gave feedback to senior executives. Triumph executives made the decision on whether to redirect their strategy in six weeks and also made a major product decision in six weeks. One executive advised: "Do something, don't just worry about decisions."

In contrast, there was little mention of real-time information from the teams making the slower decisions. What was mentioned suggested that such information was not particularly germane to their decision processes. For example, the Omicron CEO was asked to describe any quantified targets that he used to track performance. He answered that he did not use quantified targets, saying "My own goals are subjective. . . . Integrity is key for me." The VP of finance was an engineer, described as weak in financial matters. Omicron executives pondered whether to change their strategic direction for a year and then spent six more months deciding what their new strategic direction would be. The VP of manufacturing summarized: "We're slowmoving."

The evidence on real-time information use for the other teams making slow decisions is consistent with that at Omicron. For example, Alpha had no weekly operations meetings until several VPs insisted that they were necessary. Presidential had neither weekly operations meetings nor a VP of finance. Firm members described the CEO of Presidential as a "visionary" and as "a little detached from day-to-day operations," and described his key VP as "unfocused." At Neutron, no one mentioned real-time data, although there were stories of largesse such as trips to Hawaii for star design engineers and of the top management team's lack of interest in conserving cash. In these firms, the descriptions indicated that decision making was typically 
slow, and the durations of the strategic decision processes studied averaged 14 months, compared with 2.8 months at the fast firms.

Why does the use of real-time information quicken the pace of the strategic decision process? One reason may be that such information speeds issue identification, allowing executives to spot problems and opportunities sooner (Dutton \& Jackson, 1988). For example, the rationale for the round table forums with lower-level staff at Triumph was "to avoid sudden, surprising, and bad information."

A second reason is more subtle. The literature on artificial intelligence indicates that intuition relies on patterns developed through continual exposure to actual situations (Hayes, 1981; Simon, 1987). If so, executives who attend to real-time information are actually developing their intuition. Aided by intuition, they can react quickly and accurately to changing stimuli in their firm or its environment. Although the data are limited, the CEOs who relied most heavily on real-time information were also most frequently described as being intuitive. For example, the CEO at Zap was known as a "numbers" person and claimed to "over-M.B.A. it," yet he was also the CEO most strongly described as "intuitive," as "a lateral thinker," and as having "the best sense of everything in business"-despite his being the least experienced CEO in the study.

Finally, constant attention to real-time information may allow executive teams to gain experience in responding as a group. The frequent review of real-time information may develop the social routines people need to respond rapidly when pressing situations arise.

Why do the present results fail to support the view that information slows strategic decision making (Fredrickson \& Mitchell, 1984; George, 1980; Nutt, 1976)? One reason is that this view does not distinguish planning information from real-time information on competitive environments and firm performance. However, executives do make that distinction. The CEO at Promise said: "I'm a numbers guy, but I'm not heavy on analysis." Zap executives used computer models but called them "pretty elementary." On the other hand, several teams making slow decisions fit the image of information-users as bureaucratic planners (Quinn, 1980). For example, Omicron executives spent about six months developing a forecast of technical trends. Thus, it appears that real-time information, which gives executives intimate knowledge of their business, may speed decision making, but planning information, which attempts to predict the future, does not.

\section{Speed, Timing, and Number of Alternatives}

Fredrickson and Mitchell described a comprehensive decision-making process as one that includes being "exhaustive in the generation and evaluation of alternatives" (1984: 402). However, as they and others (Janis, 1982; Vroom \& Yetton, 1973) have noted, multiple alternatives are likely to slow the strategic decision process.

In contrast, the data here suggest that faster decision making was asso- 
ciated with more, not fewer, alternatives. Moreover, the sequencing of alternatives was crucial to the pace. Rapid decisions were characterized by simultaneous consideration of multiple alternatives, and the slower decisions were characterized by sequential consideration of fewer alternatives. In formal terms,

Proposition 2: The greater the number of alternatives considered simultaneously, the greater the speed of the strategic decision process.

The overall propensity of a team to use multiple simultaneous alternatives was assessed from the interview and story data. The number of alternatives was quantitatively measured in each decision by recording each unique alternative mentioned by every respondent. I also determined the timing of initiation and discarding of alternatives. Simultaneous alternatives were options that executives considered during at least partially overlapping time periods. Sequential alternatives were considered at times that did not overlap.

As Table 4 indicates, the data suggest that considering multiple simultaneous alternatives was associated with fast decisions. For example, Zap executives typically generated "multiple scenarios." The alliance decision, in which Zap executives considered bank loans, going public, and additional venture capital, in addition to the strategic alliance option, corroborates that finding. Within the strategic alliance option, Zap executives also negotiated simultaneously with several potential alliance partners.

Another example is the decision on strategic redirection at Triumph. The decision makers maintained multiple options, including sale of the firm's proprietary technology, liquidation, a new strategic direction, and tactical changes in the existing strategy, during the decision-making process. Moreover, firm informants described Harry, the CEO of Triumph, as typically retaining multiple options. One executive said, "Harry can live with a lot of ambiguity, a wide range of options .... Harry likes to have a larger set of options than most people do. He can carry many in his head at once. He thinks it's better if you can work a multiple array of possibilities instead of just a couple."

Several Promise executives claimed that team members usually generated multiple alternatives. One VP described the tactics as follows: (1) proposing a sincere alternative, (2) supporting someone else's alternative even when actually opposing it, and (3) proposing an insincere alternative, one that the proposer did not actually support. The purpose of these tactics was to "aerate" different options.

In contrast, the slower teams usually considered few alternatives and searched for a new alternative only when an old one was no longer feasible. For example, the Alpha top management team considered only one new product option for almost a year. During that time, the CEO worked alone. When the CEO finally made a formal presentation of his alternative, the entire team opposed it. Only then did Alpha executives consider a second alternative. Similarly, the Neutron team moved to an alliance only when 
TABLE 4

Alternatives

\begin{tabular}{|c|c|c|c|c|}
\hline Firm & Decision & $\begin{array}{c}\text { Number of } \\
\text { Alternatives }\end{array}$ & Alternatives & Timing \\
\hline Zap & Alliance & 4 & $\begin{array}{l}\text { Alliance } \\
\text { Public offering } \\
\text { Bank loans } \\
\text { Venture capital }\end{array}$ & Simultaneous \\
\hline Forefront & New product & 3 & $\begin{array}{l}\text { New product } \\
\text { Extension of existing } \\
\text { product } \\
\text { Status quo }\end{array}$ & Simultaneous \\
\hline Promise & Strategy & 3 & $\begin{array}{l}\text { Status quo } \\
\text { Major strategic shift into } \\
\text { new markets and } \\
\text { products } \\
\text { Minor strategic shift to } \\
\text { capitalize on sales } \\
\text { opportunities }\end{array}$ & Simultaneous \\
\hline \multirow[t]{2}{*}{ Triumph } & Strategy & 4 & $\begin{array}{l}\text { Refine current strategy } \\
\text { Sell firm's technology } \\
\text { Liquidate firm } \\
\text { Major strategic shift }\end{array}$ & Simultaneous \\
\hline & New product & 2 & $\begin{array}{l}\text { Low-end product } \\
\text { Moderate to } \\
\text { high-end product }\end{array}$ & Simultaneous \\
\hline \multirow[t]{2}{*}{ Omicron } & Strategy & 2 & $\begin{array}{l}\text { Major strategic shift } \\
\text { Better management of } \\
\text { sales and } \\
\text { manufacturing }\end{array}$ & Simultaneous \\
\hline & Strategy & 2 & $\begin{array}{l}\text { Major strategic shift in } \\
\text { distribution } \\
\text { Major strategic shift in } \\
\text { product and market }\end{array}$ & Simultaneous \\
\hline Neutron & Alliance & 2 & $\begin{array}{l}\text { In-house development } \\
\text { Alliance }\end{array}$ & Sequential \\
\hline Alpha & New product & 2 & $\begin{array}{l}\text { IBM-compatible product } \\
\text { Interface product }\end{array}$ & Sequential \\
\hline Presidential & New product & 2 & $\begin{array}{l}\text { VLSI }^{a} \text { product with U.S. } \\
\text { partner } \\
\text { Licensed product with } \\
\text { Japanese partner }\end{array}$ & Sequential \\
\hline
\end{tabular}

${ }^{\mathrm{a}} \mathrm{VLSI}=$ very large scale integrated circuit.

in-house product development plans were so delayed as to require an external product source.

Why do the results fail to support the view that consideration of multiple alternatives is time-consuming (Fredrickson \& Mitchell, 1984; Lindblom, 1959)? One reason is that alternatives are difficult to assess in isolation. For example, it is difficult to buy a car without looking at several cars. 
As studies of dialectical inquiry and multiple options have indicated (e.g., Anderson, 1983; Schweiger et al., 1986; Schwenk, 1983), the reason is that the process of comparing alternatives helps decision makers to ascertain the alternatives' strengths and weaknesses and builds decision makers' confidence that the most viable alternatives have been considered. As one Promise executive stated, "This [considering multiple alternatives] forces us into hypothesis-testing mode."

Second, having simultaneous alternatives reduces the escalation of commitment to any one option (Staw, 1981). Decision makers who pursue multiple options have a lower psychological stake in any one alternative and thus can quickly shift between options if they receive negative information on any alternative. Thus, decision makers who pursue multiple options are less likely to become psychologically trapped and can quickly act on negative information.

Third, simultaneous alternatives provide a fallback position. If one alternative fails, executives can quickly shift to a new one. For example, Zap executives simultaneously pursued negotiation with multiple possible strategic alliance partners, going public, and obtaining bank loans and venture capital. When the "first-choice" alliance partner left the negotiations, the president quickly cut a deal with the second choice. If that deal had failed, the firm had a backup line of credit and was poised to go public. The entire decision process was consummated in three months. In contrast, sequential consideration of alternatives provides no such ready fallback positions. For example, Presidential executives explored one product option for nine months. When that option collapsed, the team had nothing to fall back on, and the decision was delayed another five months while the team searched for a new option.

Finally, the view that multiple alternatives are time-consuming does not distinguish between the number of alternatives considered and the depth of analysis. The slow teams spent a great deal of time-but often on only one alternative. For example, Alpha and Presidential executives spent nine months working on single alternatives. In contrast, the fast teams pursued several alternatives, analyzed quickly. According to laboratory studies (e.g., Payne, Bettman, \& Johnson, 1988), such a breadth-not-depth decisionmaking strategy is highly efficient in situations in which time pressure is high.

\section{Speed, Power, and the Role of the Counselor}

In addition to the cognitive factors discussed above, political factors may also influence the pace of decisions (Mintzberg et al., 1976; Vroom \& Yetton, 1973). For example, Hickson and his colleagues (1986) found that resistance by influential people was a leading cause of delay in making strategic decisions in a sample of British organizations. Alternatively, when few executives are involved, a decision process can be rapid. For example, Vroom and Yetton (1973) advocated autocratic decision making in situations 
in which speed is essential. From that perspective, centralized power should quicken decision making.

In contrast, the data indicated no pattern linking decision speed to either qualitative or quantitative indicators of power centralization. Some autocrats were fast, but others were slow. ${ }^{5}$ However, the process whereby CEOs gathered advice was important. The teams making faster decisions had a two-tier advice process. Their CEOs sought counsel from all members of the top management team, but they focused on obtaining advice from one or two of the firm's most experienced executives, whom I termed "counselors." In contrast, the CEOs whose teams made slow decisions either had no counselor or had a less experienced executive in the counselor role. In formal terms,

Proposition 3: The greater the use of experienced counselors, the greater the speed of the strategic decision process.

Table 5 summarizes the data on counselors. An executive was designated a counselor when (1) team executives explicitly identified the individual as a counselor, adviser, or confidante to the CEO, (2) the description of the interaction between the $\mathrm{CEO}$ and the focal executive indicated a company-wide, rather than a functional, range of topics, and (3) there was story evidence of the CEO's seeking the counsel of the focal executive in the strategic decision studied. Table 5 also delineates each counselor in terms of age, experience, and personality descriptions provided by other executives.

Every team making rapid strategic decisions had at least one experienced counselor. For example, the CEO at Forefront described the VP of sales as his "confidante." He described their interaction as "more general than just sales," adding "When I talk with Joe it's often about company issues." In the decision studied, this VP triggered the decision by alerting the CEO to a major competitor's entry into the market. He then advised the CEO regarding competitive responses and served as a sounding board for the CEO's ideas.

Frequently, the oldest and most experienced executives filled the counselor role. For example, the counselors at Zap were 10 to 20 years older than most other team members. One counselor, the sales VP, had worked in the microcomputer industry since its inception and had top-level experience at two prominent firms. The other, the VP of engineering, had worked for 15 years at a major computer firm, where he had been a senior general manager. Zap's CEO said: "I seek the advice of Bob [sales], the most knowledgeable about the market, and Jim [engineering], the best manager." Often, counselors were well known to the CEO. For example, at Forefront, Promise, and Triumph, the CEO and counselor had previously worked together. Finally, the counselors frequently were on a career plateau, with their aspirations cen-

${ }^{5}$ Quantitative measures are explained in the Appendix; data are available from the author. 


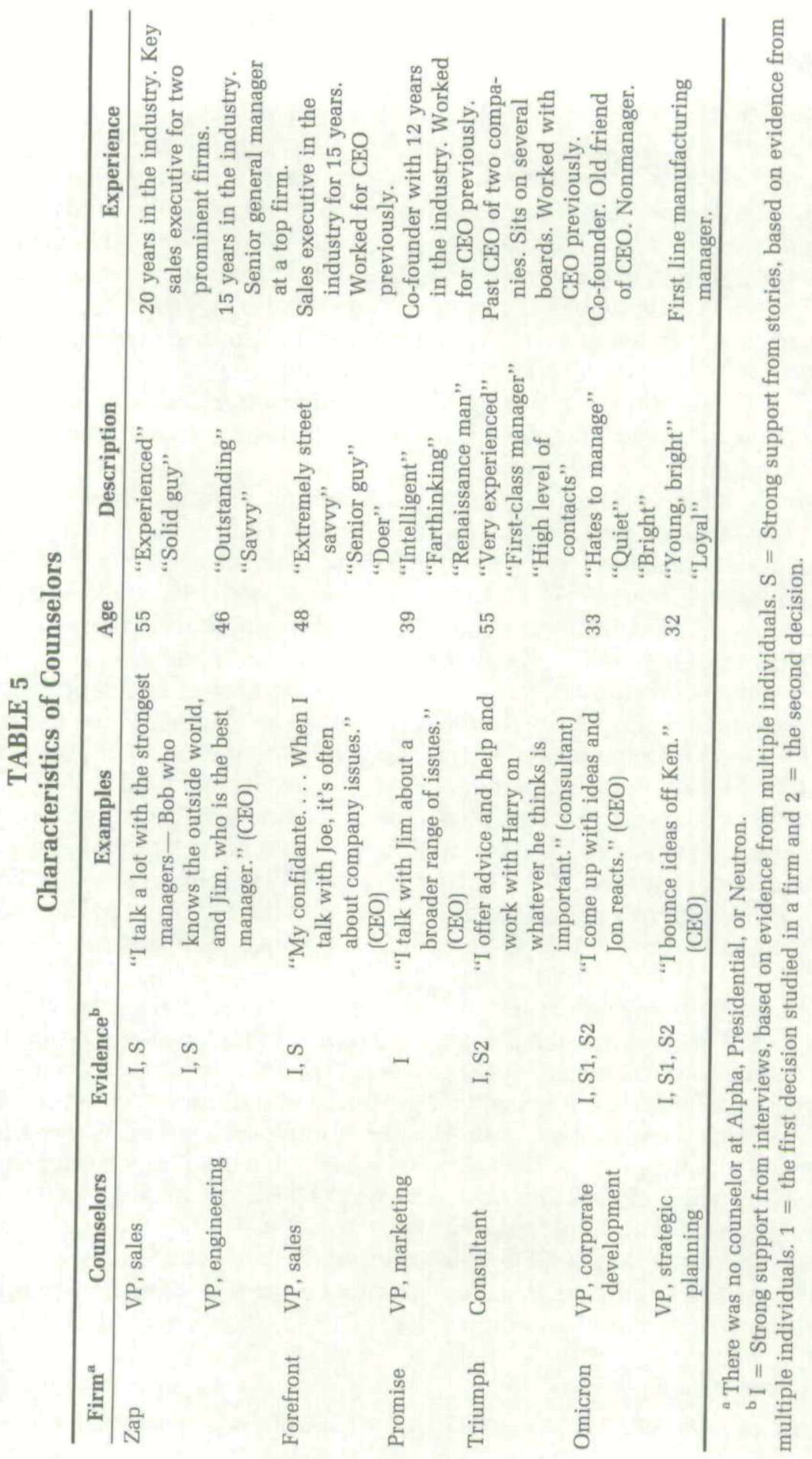


tering on personal interest. As the VP for sales at Forefront claimed, "I'm not in it for the money. It's fun to build an organization again."

Triumph is a particularly telling illustration. When the CEO joined the firm, no one on the existing team fit the profile of an older, experienced executive. What did the CEO do? He hired a consultant, whom he had known for about 15 years, to fill the counselor role. The 55-year-old consultant had been a CEO, had extensive industry contacts, and had served on several boards. His colleagues described him as "very experienced" and "a first-class manager." Firm informants credited the individual with playing a critical role in developing alternatives in the new product decision that was studied and with being a sounding board for several executives besides the CEO.

In contrast, the slow teams either did not have counselors (Alpha, Neutron, and Presidential) or had less experienced executives filling the role (Omicron). For example, one counselor at Omicron was the VP of strategic planning. At 32, he was the youngest executive on the team. His colleagues described him as "bright," but "young." The other counselor, VP for corporate development, was described as "afraid of managing."

Why does an experienced counselor speed decision making? One reason is that the counselor hastens the development of alternatives, providing a quick sounding board for ideas. Also, since counselors are often long-time associates of a CEO and are people whose career aspirations have been met, they are likely to be particularly trustworthy, enabling executives to be very open. Finally, experienced counselors are likely to provide very useful advice.

Second, an experienced counselor can help a team deal with the ambiguity of high-stakes decision making in fast-paced environments. As George noted, "In the face of uncertainty embedded in complex issues executives often find it difficult to act" (1980: 37). An experienced confidante can help overcome such barriers by sharing the decision-making effort and relating the decision to past experience. Confidence in a choice is likely to improve when the issues have been discussed with an experienced confidante.

Overall, the results fail to support the view that centralized power accelerates the pace of decision making (Vroom \& Yetton, 1973). One reason is that this view neglects the effects of procrastination. People delay because of anxiety, inadequate information, and lack of time. These barriers to decision afflict autocrats as much as collegial executives. In fact, power centralization may exacerbate such barriers by isolating a CEO and creating an informationrestrictive political culture (Eisenhardt \& Bourgeois, 1988). For example, Alpha's autocratic CEO characteristically worked alone on the new product decision. Since he worked without help, was burdened with his other duties, and was functioning in the context of a highly political team (Eisenhardt \& Bourgeois, 1988), the decision process dragged on for a year. Thus, power centralization may give a CEO the authority to decide but does not overcome the formidable information and psychological barriers to decision. 


\section{Speed, Conflict, and Resolution}

Several authors (Hickson et al., 1986; Mintzberg et al., 1976) have argued that conflict influences the length of a decision process. For example, Mintzberg and his colleagues found that conflict created interruptions in the process. Therefore, from this perspective, increasing conflict slows the pace of strategic decisions.

The data indicated no pattern linking decision speed to either the general level of conflict within a team or conflict on the decision studied. ${ }^{6}$ However, conflict resolution was crucial. The fast teams actively dealt with conflict, with decision makers resolving it on their own. In contrast, conflict resolution was problematic for the teams making slow decisions. They tended to delay until external events forced a choice. In formal terms,

Proposition 4: The greater the use of active conflict reso-

lution, the greater the speed of the strategic decision process.

Table 6 summarizes the teams' approaches to conflict resolution. I assessed conflict resolution from interview responses indicating each team's usual approach and story data indicating the specific approach taken in the decision studied. Close attention was paid to whether the process was an active one in which decision makers resolved the conflict on their own or a passive one in which decision makers delayed the resolution of conflict until deadlines approached, opponents of an alternative left the team, or external events eliminated competing alternatives.

Every team making fast decisions took an active approach to conflict. In fact, all the fast teams used the same process, termed "consensus with qualification" by a Promise VP. Consensus with qualification is a two-step process. First, a team attempts to reach consensus by involving everyone. If agreement occurs, the choice is made. However, if consensus is not forthcoming, the CEO and, often, the relevant VP make the choice, guided by input from the entire team. Zap's VP for engineering described the process as follows: "Most of the time we reach consensus, but if not, Randy [the CEO] makes the choice."

Forefront's new product decision illustrates consensus with qualification. The decision generated significant disagreement. Several executives argued that a new product would divert engineering resources from a more innovative one currently in design. Others argued that a new product was necessary to counter the moves of an important competitor. Still others argued that a simple extension of an existing product was the appropriate choice. The team held a series of meetings, and the final decision was made at one such meeting. One VP described the decision as a push for consensus, followed by the CEO's decision. Not all the VPs agreed with the choice. However, as the CEO told us: "The functional heads do the talking ... I pull the trigger."

\footnotetext{
${ }^{6}$ Quantitative measures are in the Appendix; data are available from the author.
} 
TABLE 6

Conflict Resolution $^{\mathrm{a}}$

\begin{tabular}{|c|c|c|c|c|}
\hline \multirow[b]{3}{*}{ Firm } & \multirow{3}{*}{$\begin{array}{c}\text { Active } \\
\text { Consensus } \\
\text { with } \\
\text { Qualification } \\
\end{array}$} & & & \multirow[b]{3}{*}{ Examples } \\
\hline & & \multicolumn{2}{|c|}{ Passive } & \\
\hline & & Deadlines & Consensus & \\
\hline Zap & $\mathrm{I}, \mathrm{S}$ & & & $\begin{array}{l}\text { "It's very open.... We're } \\
\text { successful most of the time } \\
\text { in building consensus. } \\
\text { Otherwise Randy [CEO] } \\
\text { makes the choice." (VP, } \\
\text { engineering) }\end{array}$ \\
\hline Forefront & I, S & & & $\begin{array}{l}\text { "The functional heads do the } \\
\text { talking ... then I pull the } \\
\text { trigger." (CEO) }\end{array}$ \\
\hline Promise & I, S & & & $\begin{array}{l}\text { "Quick decisions involving as } \\
\text { many people as possible." } \\
\text { (CEO) }\end{array}$ \\
\hline Triumph & I, S2 & & & $\begin{array}{l}\text { "Harry [CEO] just said } \\
\text { something like 'this is what } \\
\text { I've heard and it makes } \\
\text { sense.'” } \\
\text { “" 'We will do.....' Harry } \\
\text { sensed when everyone had } \\
\text { said enough and all the } \\
\text { points were out." } \\
\text { (consultant) }\end{array}$ \\
\hline Omicron & & S2 & $\mathrm{I}, \mathrm{S} 1$ & $\begin{array}{l}\text { "Snap decisions where } \\
\text { consensus is appropriate } \\
\text { and vice versa." (VP, } \\
\text { finance) }\end{array}$ \\
\hline Neutron & & S & & \\
\hline Alpha & & S & & $\begin{array}{l}\text { "Don [CEO] will bring up } \\
\text { topics over and over till } \\
\text { decisions go his way." (VP, } \\
\text { manufacturing) }\end{array}$ \\
\hline Presidential & & & I,S & $\begin{array}{l}\text { "We found that operating by } \\
\text { consensus essentially gave } \\
\text { everyone veto power..... } \\
\text { Nothing got accomplished." } \\
\text { (VP, R\&D) }\end{array}$ \\
\hline
\end{tabular}

${ }^{\mathrm{a}} \mathrm{I}=$ Strong support from interviews, based on evidence from multiple individuals. $\mathrm{S}=$ Strong support from stories, based on evidence from multiple individuals. $1=$ the first decision studied in a firm and $2=$ the second decision.

In contrast, conflict resolution was problematic in the slow teams. Sometimes, the teams waited for consensus. That behavior was typical at Presidential, where the executives agreed that "we did everything by consensus." Not surprisingly then, Presidential executives sought consensus on the new product decision that was studied. For a year, debate dragged on 
over whether they should develop the product with a U.S. partner. A decision was finally reached when several VPs who opposed that proposal left the firm, and that option was the only one still available.

Sometimes, the slow teams waited for deadlines. For example, a deadline-the annual meeting-triggered the Alpha decision. With the meeting less than a month away, the top management team rejected the CEO's first alternative of developing an IBM-compatible product. Team members believed that such a product would stretch R\&D and sales resources too thin. Frustrated by this rejection and facing an impending deadline, the CEO came up with a new alternative. Without consultation, he made the choice himself. As he stated, "I said 'to hell with it' and shoved it down their throats."

Omicron executives oscillated between consensus and snap decisions in the face of deadlines. For example, in the first Omicron decision, the team waited for about a year for consensus to emerge. It did emerge only after the VP of marketing, the main opponent of the decision that was finally made, left the firm. The second Omicron decision was triggered by a deadline. The board of directors pressured the team to articulate a strategic direction. The CEO stopped consensus-style meetings, and then met alone with several VPs. Soon after this, he chose a strategic direction on his own. As he described: "One night, I went home after Andy [VP for strategic planning] had been really high on his idea. I slept on it and canned it. I pursued my idea." The CEO's choice was a recent idea that he had never discussed within the firm. One VP claimed: "[We] make snap decisions where developing consensus over time is appropriate and vice versa."

Why is consensus with qualification rapid? One reason is that it copes actively with the conflict common to strategic decisions. It does not involve waiting for outside events, such as executives leaving or deadlines arriving, to trigger decision. Second, it is popular with executives. Most executives want to be involved, but are not anxious to make choices, except in their own areas. For example, one VP at Zap claimed: "I'm happy just to bring it [her views on the alliance] up." This satisfaction limits time-consuming political activity (Eisenhardt \& Bourgeois, 1988).

In contrast, other approaches to conflict resolution are often slow. Consensus takes time to develop and may never be achieved since many strategic decisions involve executives who hold honest differences of opinion. Although on occasion a team may reach consensus rapidly, more frequently consensual conflict resolution results in the situation described by a Presidential executive: "We found that operating by consensus essentially gave everyone veto power. There was no structure. No product would ever get out that way. Nothing got accomplished." In fact, many executives dislike the consensual approach. Typical were the comments of an Omicron VP: "I wanted Bill [the CEO] to dictate and not to waste time in meetings to bring consensus. I had more pressing problems to worry about." Waiting for deadlines is also slow because many strategic decisions do not have them. Deadlines, if they occur at all, may arise only after a long period of time, and so many strategic decisions can be postponed indefinitely. 
The results have similarities with extant literature. As Gersick's (1988) work would predict, the slow teams accelerated their decision processes in the face of deadlines. However, they did not shift to the process used by fast decision-making teams. Rather, they shifted to the noncomprehensive decision process many authors have described (e.g., Fredrickson \& Mitchell, 1984; Lindblom, 1959). For example, the CEO at Alpha made a snap decision to develop an interface product that no one had seriously analyzed. Similarly, the CEO at Omicron chose a strategy that involved major shifts in engineering and marketing but never discussed it within the firm. In those cases, the executives speeded up the process by making snap choices. Although others have described such a noncomprehensive process as fast (Fredrickson \& Mitchell, 1984), the evidence here suggests that the approach was embedded in a slow decision process. Thus, noncomprehensive describes the way that slow teams accelerate.

\section{Speed, Fragments, and Decision Integration}

The final critical difference between teams making fast and slow strategic decisions lies in the web of relationships among those decisions. The evidence indicates that fast teams attempted to integrate strategic decisions with one another and with tactical plans. In contrast, the teams making slower decisions treated decisions as discrete and even disconnected events. In formal terms,

\section{Proposition 5: The greater the integration among deci-} sions, the greater the speed of the strategic decision process.

Decision integration was assessed using qualitative evidence for teams' usual approaches to decision integration and stories of the specific decisions. Decisions were examined in relation to their integration with past and current strategic decisions and tactical plans like budgets and engineering schedules.

The teams making fast decisions more completely integrated those decisions with other major decisions and with tactical plans. For example, Triumph executives claimed that when they made a major decision, they also developed plans to manage the worst case outcome. One VP termed this practice "knowing your way out of each decision." During the time of the strategic redirection decision studied, the team members integrated their choice of strategy with a new product decision, tactical plans for execution, and a worst-case plan to sell firm technology.

The decision began with the arrival of a new CEO. According to firm executives, the CEO spent about two weeks conferring with people throughout the firm. Gradually, he shifted the team's attention to articulation of alternative paths for the firm, including the sale of technology, liquidation, a new strategic direction, and tactical changes to the existing strategy. In the process of developing and choosing among these alternatives, the executives also decided the specifications for a new product, scheduled the timing of three new product releases, and rebudgeted the entire firm for the coming 
year. At the end of six weeks, a new strategic direction was set, a new product choice was made, and tactical plans in the form of detailed budgets and engineering schedules were complete.

Similarly, the Zap alliance decision was integrated with other decisions. Although Zap executives chose an alliance to solve their short-term cash problems, they simultaneously addressed future cash needs by planning an initial public offering. The executives made tactical plans for each functional area and set milestones whose arrival would trigger the public offering. Thus, after three months, Zap executives emerged with a plan that coordinated the short-term decision to form an alliance with the long-term decision to make a public offering, tactical plans to execute a public offering, and contingency plans to obtain backup bank credit.

In contrast, the slow teams made decisions in fragments, with little concern for how decisions related to each other or to tactical plans. For example, Presidential executives struggled for over a year deciding whether to develop a new product. Only after the product decision was made did they consider how to integrate the product into their existing product lines. Presidential executives were still trying to decide after a year of deliberation. As one executive said, "We don't have a strategy of what to do with the [product] yet." Because of the delay, the new product still had not produced revenue.

Similarly, Omicron executives reported that they enjoyed thinking about strategic decisions in the abstract, "on a blank sheet of paper." Their approach to the strategic redirection decisions corroborates this view. Omicron executives spent about a year deciding whether to change strategy without any serious consideration of what the new strategy should be. Having made the decision to switch, they then spent another six months choosing the new strategic direction. Specific product choices still had to be made, and as this research concluded, tactical plans, such as changes in engineering priorities and budgets, had not been made. It is striking that, as described above, Triumph executives made a similar decision - and chose a new product, scheduled three product releases, and rebudgeted the firm - in six weeks, compared to the eighteen months spent at Omicron on the initial decision.

Why is greater decision integration associated with faster decision making? One reason is that decision integration helps executives to analyze the viability of an alternative more quickly. Second, it helps them to cope with the ambiguity of high-stakes decision making. As the literature on active coping suggests (Gal \& Lazarus, 1975), development of concrete ties with other major decisions and decision details may alleviate the anxiety that can plague executives as they face high-stakes decisions. The process of developing specific plans may give executives a better understanding of alternatives and provide feelings of competence and control (Langer, 1975). These in turn produce the confidence to act. Also, such integration may limit discontinuities between decisions. In contrast, lack of decision integration keeps decision making at an abstract level, where anxiety can loom large. 
The data, especially those from the slow teams, support this interpretation. For example, one Omicron executive said, "We don't have the confidence to know how to do it [set strategic direction]." Another summarized the prevailing view: "Maybe we saw too much mystery. Maybe we needed more gut. You don't know any more even though you wait."

Why do the results fail to support previous views of decision integration as slow (Fredrickson \& Mitchell, 1984; Quinn, 1980)? One reason is that prior research has neglected the effects of concrete planning on actively coping with uncertainty. Second, the prior views were predicated on the idea that executives achieve integration through complex formal planning systems. For example, Quinn noted: "The planning activity often tended to become a bureaucratized, rigid, and costly paper-shuffling exercise" (1980: 2). However, the fast decision teams did not integrate decisions using complex systems involving a wide range of integration techniques, consultation with outsiders, or large expenses (Fredrickson \& Mitchell, 1984). Rather, they maintained mental maps of how decisions fit together and supplemented those maps with brief plans and action-oriented, operational documents such as budgets and engineering schedules. For example, Promise executives summarized their strategic direction with a three-page statement. Overall, the fast decision-making teams simultaneously kept in mind multiple decisions. In contrast, the slow teams were linear thinkers, treating each decision as a discrete event.

\section{HOW DOES STRATEGIC DECISION SPEED LINK TO PERFORMANCE?}

The second research question was: How does the speed of strategic decision relate to performance? Firm performance was assessed by (1) CEOs' numerical self-reports of company effectiveness (0 to 10 scale), (2) a comparison of that rating to ratings CEOs gave to competitors, and (3) sales growth and profitability figures before and after the study. At the decision level, I assessed performance by whether team executives supported a decision after the fact, made similar decisions later, and implemented the decision. Table 7 summarizes these data.

The data support the proposition that faster decision making is associated with better performance. Admittedly, the evidence is tenuous, because performance can depend upon many factors, including those described in earlier studies (Bourgeois \& Eisenhardt, 1988; Eisenhardt \& Bourgeois, 1988). Also, fast decision making using a different style than shown in these cases might lead to different results. For example, snap decision making by an impulsive CEO might lead to fatal errors. However, the proposition is presented because the performance differences were substantial and the data strongly suggested underlying dynamics that support the relationship. In formal terms,

Proposition 6: The greater the speed of the strategic decision process, the greater the performance in high-velocity environments. 


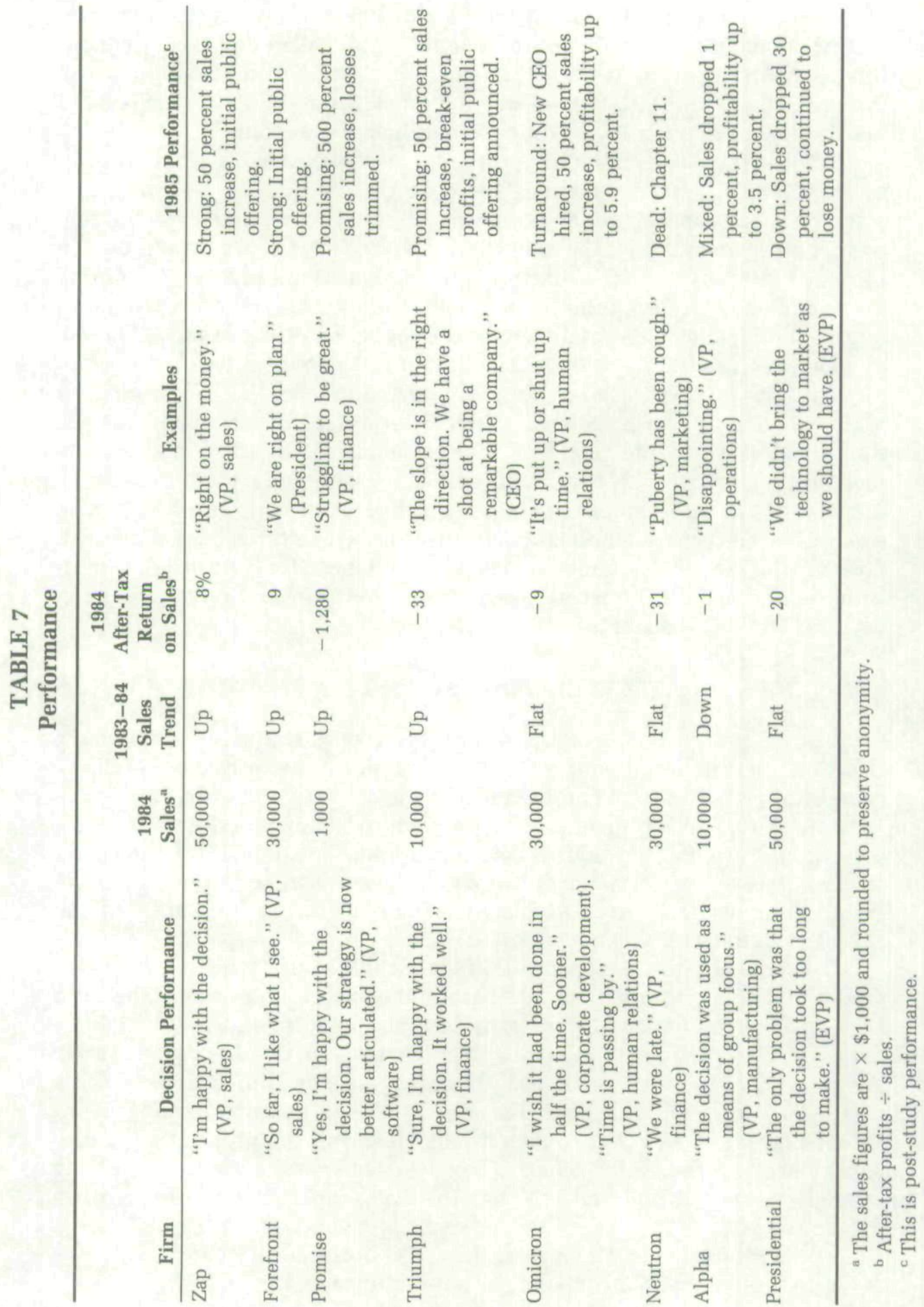


For example, Zap's performance has been spectacular, with sales growing at 25 to 100 percent per quarter. Zap executives considered the alliance decision to have been successful and have since executed other similar decisions. Forefront's executives also positively evaluated their decision. One stated: "So far, I like what I see." Another said: "The verdict so far is favorable." Forefront has been a strong performer, with sales tripling and after-tax profits running at 9 percent during the year after the study. Similarly, the Triumph and Promise executives assessed their decisions positively. For example, one VP at Promise said, "Yes, I'm happy with the decision. Our strategy is now better articulated." Another at Triumph said, "Sure, I'm happy with the decision. It worked well." At the time of the study, both firms were struggling. Promise was an early venture just getting started, and Triumph had recently replaced its CEO. Since the study, sales at Promise have soared 500 percent, and Triumph has become one of only two survivors in its niche and has announced plans to go public.

By contrast, slow decision making was associated with poor performance. For example, Presidential executives viewed their new product decision as good, but too slow. As one VP told us: "The only problem was that it took too long to make the decision." Another said: "Our products were too late and they were too expensive." As the firm fell behind its competitors, sales tumbled 30 percent in the year after this study, and the firm continued to lose money. The delay at Neutron proved costly as well. The market opportunity was missed, and the firm went bankrupt a year after the study. At Alpha, the executives expressed relief that the CEO's original alternative was shelved. However, the firm continued to drift, with stagnant sales and profits.

Omicron is an interesting case because there was a performance turnaround. During this study, the firm experienced flat sales and mounting losses. Omicron executives attributed much of the problem to the slow decision making of the CEO. As one VP said: "Bill's procrastination caused the problem." But Bill was replaced and, although the data are limited, the new CEO appeared to change the decision process. One VP reported: "Jim [the new CEO] has a different style, he pays more attention to the numbers." Another claimed: "He is not caught in analysis paralysis." Jim was also described by the same adjectives that were used to describe the CEOs of the fast decision teams - "decisive," "operations-focused," "hands-on," and "instinctive." He described others as either fast, indicating approval, or slow, indicating disapproval. Although Jim made several changes that seemed to improve firm performance (Eisenhardt \& Bourgeois, 1988), the team agreed that he was "accelerating the decision process." Consistent with the proposition linking decision speed and performance, Omicron attained a 50 percent sales increase and became profitable during Jim's first year as CEO.

Why is slow decision making problematic? One reason may be learning. Executives learn by making decisions, but if they make few decisions, as slow decision makers do, they learn very little. So they are likely to make 
mistakes. A second reason is that, in fast-paced environments, opportunities move quickly, and once a firm is behind, it is difficult to catch up. The qualitative data were particularly supportive of this point. For example, a Presidential VP said: "We tried to use consensus, but it gave everybody veto power and we ended up doing a random walk. Our products were too late and they were too expensive." Presidential still has not caught its competitors. Neutron executives echoed this view. For example, the VP of finance observed: "The big players [customers and distributors] were already corralled by the competition. We were late." The firm never regained its early momentum and went bankrupt.

In contrast, the strong performers reiterated the importance of keeping pace with the environment. A Promise VP said: "You have to keep up with the train." Zap executives claimed: "If you don't innovate, someone else will." Their CEO argued that the best management training was playing video games, to hone fast decision-making skills. The sales VP at Forefront said: "You've got to catch the big opportunities." An executive at Triumph advised: "Do something, don't just sit around worrying about decisions." This quote may summarize such ideas best: "No advantage is long-term because our industry isn't static. The only competitive advantage is in moving quickly" (VP of finance, Promise).

\section{TOWARD A MODEL OF THE SPEED OF STRATEGIC DECISION MAKING}

This research explored the speed of strategic decision making in a highvelocity environment. Such environments are particularly challenging because information is poor, mistakes are costly, and recovery from missed opportunities is difficult. The findings are a set of propositions, depicted in Figure 1. They are organized around three mediating processes.

Several of the propositions focus on how executives making fast decisions accelerate their cognitive processing. For example, these executives immerse themselves in real-time information on their environment and firm operations (Proposition 1). The result is a deep personal knowledge of the enterprise that allows them to access and interpret information rapidly when major decisions arise. In contrast, the slow executives have a less firm grasp on their business. So, when strategic decisions occur, they grope about, try to plan, and have trouble focusing on key information. The executives making fast decisions also use tactics to accelerate analysis of information and alternatives during the decision process. For example, they examine several alternatives simultaneously (Proposition 2). The comparison process speeds their analysis of the strengths and weaknesses of the options. They also gather advice from everyone but focus their attention on the most experienced executives, who are likely to have the most useful advice (Proposition 3). Finally, they integrate key decisions and tactical planning within the decision process (Proposition 5). Doing so quickens executives' assessment of the viability of alternatives. Overall, the executives making fast decisions 
FIGURE 1

A Model of Strategic Decision Speed in High-Velocity Environments ${ }^{a}$

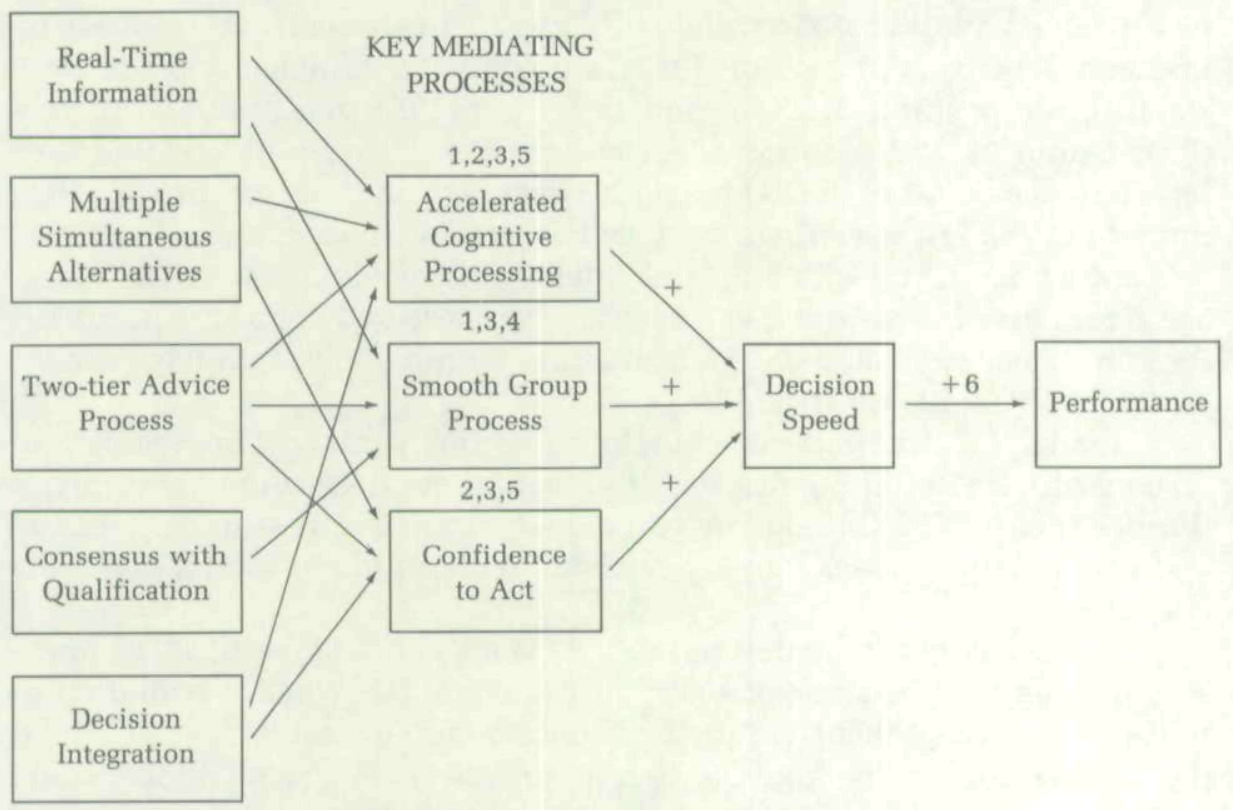

${ }^{a}$ Numbers correspond to propositions in the text.

accelerate their cognitive processing by using efficient problem-solving strategies that maximize information and analysis within time constraints (Hayes, 1981; Payne et al., 1988). These strategies are neither comprehensive nor noncomprehensive, but rather a mix of both.

Second, several of the propositions describe how executives making fast strategic decisions create a smooth group process. For example, constant perusal of real-time information allows executives to rehearse their performance routines with one another (Proposition 1). The result is a team conditioned to work together successfully in turbulent situations. Similarly, although the consensus-with-qualification approach emphasizes the roles of executives in their own areas, it also rests on participation by the entire team (Proposition 4). The data suggest that executives favor this approach. They want a voice but do not necessarily want to make choices, except in their own arenas. Finally, the fast teams use a two-tier advice process (Proposition 3). This advice process emphasizes the role of counselors, but all are consulted and can participate if they choose. In sum, the fast decision makers create a smooth group process through rehearsal and participation. In particular, these behaviors yield fast decisions because they combine participation and decisiveness in a way that is popular with executives. 
Several propositions also converge on the importance of confidence in high-stakes decision making. Anxiety can cripple decision makers in such situations (George, 1980). The teams making fast decisions engage in behaviors to cope with this anxiety and build confidence. One tactic is to rely on the counsel of experienced executives, who impart confidence and a sense of stability (Proposition 3). A second tactic is to seek multiple alternatives (Proposition 2). Doing so gives decision makers the confidence that they have surveyed most of the likely options, leaving "no stone unturned." Most important, the fast executives tie together strategic decisions and concrete operating plans (Proposition 5). This attention to day-to-day detail and linkage across major decisions gives a sense of mastery and control that imparts the confidence to act and creates a structure within which action is possible (Gal \& Lazarus, 1975; Langer, 1975).

Finally, the findings corroborate an earlier study by Bourgeois and Eisenhardt (1988) linking fast decision making with effective performance (Proposition 6). The findings suggest a configuration of cognitive, political, and emotional processes that is associated with rapid closure on major decisions.

This article began by describing the extant views of fast strategic decision making: that is, strategic decision making is fast when it is more centralized, less comprehensive, and less conflictual. The results fail to support these views. Rather, the findings here suggest that comprehensiveness is not a single construct. Consistent with laboratory studies of decision making under time pressure (Payne et al., 1988), the results suggest that fast decision makers try to be efficient in their use of time. So, they are comprehensive in some ways, but not in others. For example, they seek advice from the best sources but not from everyone, and they develop multiple alternatives but analyze them quickly in comparison. "Noncomprehensive" better describes how slow teams accelerate. The results also differ from the view (Hickson et al., 1986; Mintzberg et al., 1976) that conflict is an important determinant of pace. One reason may be that those authors focused on situations where conflict slowed the pace but not on equally conflictual situations in which conflict was resolved. Thus, they could not observe the essential role of conflict resolution in determining decision speed (Gersick, 1989; Tjosvold, 1985). Finally the centralization view (e.g., Vroom \& Yetton, 1973) neglects that autocrats become bogged down by inadequate information, excessive workloads, and anxiety as much as, and perhaps more than, others do.

\section{CONCLUSIONS EMERGING FROM A RESEARCH PROGRAM}

This work is part of a larger research program on strategic decision making in high-velocity environments. The initial article (Bourgeois \& Eisenhardt, 1988) identified some attributes of successful decision making in this setting. A subsequent article on politics explored one of those attributes: the relationship between a decisive CEO and a powerful executive team (Eisenhardt \& Bourgeois, 1988). The present article explores a second 
attribute: fast strategic decision making. The results link fast decisions to several factors, including the use of real-time information, multiple alternatives, counselors, consensus with qualification, and decision integration.

From this research program, a perspective is beginning to take shape that challenges some traditional thinking about strategic decision making. This emergent view places crucial importance on top management teams. Others (Hickson et al., 1986; Mintzberg et al., 1976) have argued that decision characteristics are paramount. The view here is that, although decision characteristics are important, there are recurring interaction patterns among executives that also profoundly influence strategic decision making and, ultimately, firm performance.

Second, this view emphasizes a complex perspective on cognition. A rational versus incremental paradigm has dominated the literature on strategic decision making, with the rational model often cast as a straw man (Anderson, 1983; Cyert \& March, 1963; Lindblom, 1959; Quinn, 1980). The results of this research program suggest the limitations of that dichotomy. People are boundedly rational but are also capable of engaging in sensible problem-solving strategies to help compensate for their limitations. In this view, interesting research questions center on problem solving strategies, and results from the artificial intelligence literature may be particularly relevant.

Finally, the emergent perspective highlights emotion as integral to highstakes decision making. The politics article (Eisenhardt \& Bourgeois, 1988) indicated that intense emotions such as frustration, distrust, and loyalty shaped organizational politics. Similarly, the present article identifies confidence and anxiety as key factors influencing the pace of decision closure. Thus, the view emerging from this research program is that emotion is critical for understanding strategic decision making.

The current article and the overall research program address the process of strategic decision making, especially in fast-paced, technology-driven environments. The microcomputer industry is admittedly an extreme situation, a setting that places an extraordinary premium on fast, high-quality decision making. However, if the ideas presented here survive empirical tests, they offer lessons for all organizations as they face an increasingly turbulent world.

\section{REFERENCES}

Anderson, P. 1983. Decision making by objection and the Cuban missile crisis. Administrative Science Quarterly, 28: 201-222.

Astley, W. G. 1978. Sources of power in organizational life. Unpublished doctoral dissertation, University of Washington, Seattle.

Bell, C. G. 1984. The mini and micro industries. IEEE transactions on computing. 17(October): 14-29.

Bourgeois, L. J. 1980. Performance and consensus. Strategic Management Journal, 1: 227-248.

Bourgeois, L. J., \& Eisenhardt, K. 1987. Strategic decision processes in Silicon Valley: The anatomy of a "living dead." California Management Review, 30: 143-159.

Bourgeois, L. J., \& Eisenhardt, K. 1988. Strategic decision processes in high velocity environments: Four cases in the microcomputer industry. Management Science, 34: 816-835. 
Dutton, J., \& Jackson, S. 1988. Discerning threats and opportunities. Administrative Science Quarterly, 33: 370-387.

Eisenhardt, K. 1989. Building theories from case study research. Academy of Management Review, 14: in press.

Eisenhardt, K., \& Bourgeois, L. J. 1988. Politics of strategic decision making in high-velocity environments: Toward a midrange theory. Academy of Management Journal, 31: 737770 .

Eisenhardt, K., \& Bourgeois, L. J. 1989. Charting strategic decisions: Profile of an industry star. In M. Van Glinow \& S. Mohrmann (Eds.), Managing complexity in high technology organizations, systems, and people: Forthcoming. New York: Oxford University Press.

Fredrickson, J., \& Iaquinto, A. 1987. Incremental change, its correlates, and the comprehensiveness of strategic decision processes. Academy of Management Proceedings: 26-30.

Fredrickson, J., \& Mitchell, T. 1984. Strategic decision processes: Comprehensiveness and performance in an industry with an unstable environment. Academy of Management Journal, 27: $399-423$.

Gal, R., \& Lazarus, R. 1975. The role of activity in anticipating and confronting stressful situations. Journal of Human Stress, 2: 4-20.

George, A. 1980. Presidential decision making in foreign policy. Boulder, Colo.: Westview Press.

Gersick, C. 1988. Time and transition in work teams: Toward a new model of group development. Academy of Management Journal, 31: 9-41.

Gersick, C. 1989. Marking time: Predictable transitions in task groups. Academy of Management Journal, 32: 274-309.

Glaser, B., \& Strauss, A. 1967. The discovery of grounded theory: Strategies for qualitative research. London: Wiedenfeld and Nicholson.

Hayes, J. 1981. The complete problem solvers. Philadelphia: Franklin Institute Press.

Hickson, D., Butler, R., Gray, D. Mallory, G., \& Wilson, D. 1986. Top decisions: Strategic decision making in organizations. San Francisco: Jossey-Bass.

Hof, R. 1984. Why once-ambitious computer firm quit. Peninsula Times Tribune, September 29: B1.

Huber, G. 1985. Temporal stability and response-order biases in participant descriptions of organizational decisions. Academy of Management Journal, 28: 943-950.

Janis, I. 1982. Victims of groupthink (rev. ed.). Boston: Houghton-Mifflin.

Langer, E. 1975. The illusion of control. Journal of Personality and Social Psychology, 32: 311-328.

Lindblom, C. 1959. The science of "muddling through." Public Administration Review, 19: 79-88.

March, J., \& Olsen, J. 1976. Ambiguity and choice in organizations. Bergen, Norway: Universitetsforlaget.

Miles, R., \& Snow, C. 1978. Organizational strategy, structure, and process. New York: McGraw-Hill Book Co.

Mintzberg, H. 1973. Strategy making in three modes. California Management Review, 16: $44-53$.

Mintzberg, H., Raisinghani, D., \& Theoret, A. 1976. The structure of "unstructured" decision processes. Administrative Science Quarterly, 21: 246-275.

Nutt, P. 1976. Models for decision-making in organizations and some contextual variables which stipulate optimal use. Academy of Management Review, 1: 147-158. 
Nystrom, P., \& Starbuck, W. 1984. To avoid organizational crises, unlearn. Organizational Dynamics, 12(Spring): 53-65.

Payne, J., Bettman, J., \& Johnson, E. 1988. Adaptive strategy selection in decision making. Journal of Experimental Psychology, 14: 534-552.

Pfeffer, J. 1981. Power in organizations. Marshfield, Mass.: Pitman Publishing.

Quinn, J. B. 1980. Strategies for change: Logical incrementalism. Homewood, Ill.: DowJones-Irwin.

Schweiger, D., Sandberg, W., \& Ragan, J. 1986. Group approaches for improving strategic decision making: A comparative analysis of dialectical inquiry, devil's advocacy, and consensus. Academy of Management Journal, 29: 51-71.

Schwenk, C. 1983. Laboratory research on ill-structured decision aids: The case of dialectical inquiry. Decision Sciences, 14: 140-144.

Schwenk, C. 1985. The use of participant recollection in the modeling of organizational decision processes. Academy of Management Review, 10: 496-503.

Simon, H. 1987. Making management decisions: The role of intuition and emotion. Academy of Management Executive, 1: 57-64.

Staw, B. 1981. The escalation of commitment to a course of action. Academy of Management Review, 6: 577-587.

Staw, B., Sandelands, L., \& Dutton, J. 1981. Threat-rigidity effects in organizational behavior: A multilevel analysis. Administrative Science Quarterly, 26: 501-524.

Sutton, R., \& Callahan, A. 1987. The stigma of bankruptcy: Spoiled organizational image and its management. Academy of Management Journal, 30: 405-436.

Tjosvold, D. 1985. Implications of controversy research for management. Journal of Management, 11: 21-37.

Vroom, V., \& Yetton, P. 1973. Leadership and decision making. Pittsburgh, Pa.: University of Pittsburgh Press.

Weick, K. 1979. The social psychology of organizing (2d. ed.). Reading, Mass.: AddisonWesley.

Yin, R. 1984. Case study research: Design and methods. Beverly Hills: Sage Publications.

\section{APPENDIX \\ Quantitative Measures}

Goal conflict (Bourgeois, 1980). The goal question consisted of a list of ten organizational goals, introduced by: "In the space provided, indicate how important each of these goals is to your firm" ( $0-10$ scale). The goals included: long-term profitability, growth, innovation, stock price, company prestige, and community service. Each top management team's standard deviation on each of the goal items was summed.

Policy conflict (Bourgeois, 1980). The questionnaire contained a matrix in which 12 key decision areas ran down one side of the paper and executive titles ran across the top. The text read: "Here is a list of various decision areas which may be of strategic importance to your firm. Please indicate how important each of these decision areas is to the long run health of your firm" ( $0=$ not at all important, $10=$ extremely important). Decision areas were: marketing strategies and product pricing, R\&D project selection, expansion of production capacity, major financings, and restructuring the organization. The team standard deviation on each of the items was summed.

Interpersonal disagreement (Astley, 1978). Conflict was also measured in terms of interpersonal disagreement. In order to obtain interpersonal disagreement scores for each top management team, each executive was asked to evaluate the frequency of disagreement with each 
other specific member of the team. The text read: "How often during the process of deliberating, debating, and making policy decisions, have you found yourself in open disagreement with the suggestions or proposals of each of these individuals?" $(0=$ never, $10=$ constantly $)$. The mean score for each executive and then the overall mean for the team were computed.

Power (Astley, 1978). Using the same key-decision-area matrix described above, we asked executives to assign scores to each manager on each decision in terms of how much influence that manager had on the decision $(0=$ no influence, $10=$ very great deal of influence). The text read: "Now, for the same list of decision areas (excepting those scored 0 or 1), indicate how much influence you think each manager has in making decisions concerning that decision area. If the manager has a very great deal of influence over the decision area, give a rating of 10 ; no influence would score 0 ; and so on." Computing mean scores every other respondent assigned to an executive involved three steps: a mean power score for each person on each decision; a mean score for each decision area ( $\& \& D$, marketing, finance, manufacturing, and organization); and an overall mean.

Kathleen M. Eisenhardt received her Ph.D. degree in organizational behavior from Stanford University. She is an assistant professor in the Department of Industrial Engineering and Engineering Management, School of Engineering, at Stanford University. Her research interests include strategic decision making and entrepreneurship in hightechnology environments, agency theory, and inductive methods. 
Copyright of Academy of Management Journal is the property of Academy of Management and its content may not be copied or emailed to multiple sites or posted to a listserv without the copyright holder's express written permission. However, users may print, download, or email articles for individual use. 